\title{
Factors Influencing Investment Decision of the Individual Related to Selected Individual Investors in Chennai City
}

\author{
S.Hemalatha
}

\begin{abstract}
The purpose of investment is to gain a profitable returns by investing money .A variety of investment avenues are available to individuals fixed deposit, insurance policies, government securities, corporate bonds, Shares and mutual fund, real estates, commodities, chit funds, post office schemes, investment in gold and silver. Various factors influences the investment decision of the individual. Demographic profile also plays a vital role in investment decision of the individual. Thus, this study aims to find out attitudedifferences in the perception of individual investors on factors influencing investment decision on the basis demographical profile of the individuals. The survey was collected from 374 individuals in Chennai, Tamil Nadu. Descriptive statistics (t-test and f-test) are used to find out the value of mean, standard deviation, standard error, mean of factors influencing individual investment decision. The results found that factors of selection of investment varies according to gender, age, occupation, usage of internet, level of computer knowledge, usage of online trading.
\end{abstract}

Keywords - investment, investors, occupation, Chennai

\section{INTRODUCTION}

Individual invest their surplus money in any of the investment avenue depending on their risk taking capacity. Thus, individual's financial decision making depends on their attitude and behaviour. Demographic profile also plays a vital role in investment decision of the individual. "No pain, no gain" is the general belief in the investment management. More risk lead to more profits. Investors invest in safe investment in order to reduce the risk in investment. But in such case investors can expect only moderate profit. Individual's investment decisions are influenced by various factors. Earlier researchers recognised the following; capital appreciation, tax benefit, expected return, liquidity, risk minimization, financial security. Hence, keeping this in mind, the present study attempts to find out attitudedifferences in the perception of individual investors on factors influencing investment decision on the basis of age, gender, occupation, the level of computer knowledge, number of years of usage of internet, number of years of usage of online trading.

\section{REVIEW OF LITERATURE}

Investing behaviour of individual investors depends on various factors which includes their personal profile too. The following studies are reviewed in this area:

Ramanujam and Chitradevi (2012) found that socioeconomic variables viz., age, gender, income, education and occupation make significant impact while deciding on the investment patterns for investment. Kabra et.al (2010) found that investor's age and gender affected their risk taking capacity. Saugat Das et al. (2014) found that demographic variables such as age, gender, education, occupation plays a very important role in investment decision. Manoj Kumar Dash(2010) found that demographical factors like age, income, occupation influences the investment pattern of the individual. Thulasipriya (2015) identified that Tax benefit, security \& safety, high returns, liquidity arethe major factors considered by investors before investing. Dr. C. M. Shinde ,PriyankaZanvar(2015) identified that demographic factors of investors such as age, educational qualification, income level, effect the investor's level of risk tolerance influences individual's investment decision. S. Umamaheshwari and M. Ashojkkumar (2014) found that there is a significant connection between the demographic factors of salaried class investors and their acquaintance with the investment policies, and also between satisfaction level on investment policies. Dr.Sathya Swaroop Debasish (2011) found that investors preferred those types of avenues which are safe, lead to secured future, liquidity and meet future contingency .Dhiraj Jain and Nikhil Mandot (2012) found that that various demographic factors like age, marital status, gender, city, income level, market knowledge, occupations and qualifications have major impact on investment decision of investors in Rajasthan. L.Pandiyan and Dr. T. Arayanathan(2012) found that there is a signifiancant differences in attitude towards savings and investment between male and female salaried group. Attitude of investors relate to income level and age. B.B.S Parihar and K.K. Sharma (2012) found that the major factors influencing individual investors are safety, return, tax benefit, liquidity, convenient and affordability. K. Parimalakanthi and Dr.M. Ashok Kumar (2015) found that safety of principal amount, liquidity, income stability, and appreciation are the major factors influencing individual investment decision.Saugat das and Ritika Jain (2014) found that found that demographic variables such as age, gender, education, occupation plays a very important role in investment decision. From the above study, the six factors (Capital Appreciation, Tax Benefit, Expected Return, future Financial Security, Liquidity/ Marketability, Risk Minimisation ) have been selected for the current study to measure factors that influence the investment decision of the individual investment decision. 


\section{RESEARCH METHODOLOGY}

The nature of study is Empirical study. The method of data collection was both primary data and secondary data. The instrument used is Questionnaire. The Questionnaire has two sections: Demographical Profile and six factors influencing investment of the individual. The study is conducted in Chennai. A five point likert scale was used. The respondents of the study were individual investors. It was proposed to have a sample of around 500. For the purpose 750 structured, non-disguised questionnaire were sent to the respondents with a request letter. 400 questionnaire were returned by the respondents of which 374 fully completed questionnaire were taken for the study. In pilot Study, through Cronbach alpha coefficient, values ranging from 0.709 to 0.923 obtained in this study, which shows that the scale reliabilities are above the commonly accepted threshold value of 0.70 (Hair et al., 1998). In order to ensure the content validity, a pilot study was conducted by distributing the questionnaires among thirty shareholders who are highly knowledgeable in areas pertaining to online share trading. Comments and suggestions from the experts on both the content and writing skill were taken into consideration to improve the validity of the questionnaire.

\section{DATA ANALYSIS AND RESULTS INTERPRETATION}

Frequency and percentage analysishas been applied to study various personal profiles such as age, gender, qualification, occupation, annual income, level of computer knowledge, period of internet usage and period of online trading usage. Descriptive statistics are used to find out the value of mean, standard deviation, standard error, mean of factors influencing individual investment decision.

Table 1.1 Table showing demographical profile of the respondents

\begin{tabular}{|l|l|l|}
\hline & Frequency & Percentage \\
$\mathrm{N}=374$ & $100 \%$ \\
\hline Gender & 269 & \\
Male & 105 & $71.9 \%$ \\
Female & & $28.1 \%$ \\
\hline Age & 104 & \\
$\quad<30$ & 146 & $27.8 \%$ \\
$31-40$ & 105 & $39 \%$ \\
$41-50$ & 19 & $28.1 \%$ \\
Above 50 & & $5.1 \%$ \\
\hline Qualification & & \\
HSC/Diploma & 6 & $1.6 \%$ \\
Under Graduate & 116 & $31.0 \%$ \\
Post Graduate & 154 & $41.2 \%$ \\
Professionals & 98 & $26.2 \%$ \\
\hline Occupation & & \\
Salaried & 268 & $71.7 \%$ \\
Self Employed & 93 & $24.9 \%$ \\
Others & 13 & $3.5 \%$ \\
\hline Annual Income & & \\
Below Rs.25,000 & 17 & $4.5 \%$ \\
Rs. 25,000 - Rs. 50,000 & 82 & $21.9 \%$ \\
Rs. 50,000 - Rs. 75,000 & 150 & $40.1 \%$ \\
Above Rs. 75,000 & 125 & $33.4 \%$ \\
\hline Internet Usage & & \\
2-5 years & 52 & $13.9 \%$ \\
5-8 years & 74 & $19.8 \%$ \\
8-10 years & 80 & $21.4 \%$ \\
Above 10 years & 168 & $44.9 \%$ \\
\hline Online Trading & 101 & $27 \%$ \\
<2 years & 98 & $26.2 \%$ \\
2-5 years & 61 & $16.3 \%$ \\
5-8 years & 37 & $9.9 \%$ \\
8-10 years & 77 & $20.6 \%$ \\
Above 10 years & & \\
\hline & & \\
\hline
\end{tabular}

1.2 Individual investment decision and demographical profile

Thus, the current study aims to evaluate the role of gender in and table shows the factors based on gender. 
Table 1.2 Factors influencing investment decisions based on gender

\begin{tabular}{|l|l|l|l|l|}
\hline Factors & $\begin{array}{l}\text { Mean } \\
\text { Male } \\
\text { N=269 }\end{array}$ & $\begin{array}{l}\text { Mean } \\
\text { Female } \\
\text { N= 105 }\end{array}$ & t-test & $\begin{array}{l}\text { Level of } \\
\text { significance }\end{array}$ \\
\hline Capital appreciation & $\mathbf{4 . 2 6}$ & 4.16 & 17.909 & $\mathbf{. 0 0 0}$ \\
\hline Tax Benefit & 3.29 & 3.47 & 0.38 & 0.846 \\
\hline Expected Returns & 4.38 & $\mathbf{4 . 5 5}$ & 11.131 & $\mathbf{0 . 0 0 1}$ \\
\hline Financial Security & 3.96 & 4.50 & 0.952 & 0.330 \\
\hline Liquidity & 4.19 & 4.21 & 0.898 & 0.344 \\
\hline Risk minimization & 2.83 & 3.43 & 2.336 & 0.127 \\
\hline
\end{tabular}

Table 1.2 reveals that there is a significance differences in individual considering factor such as capital appreciation, expecting return as major factor for investment decisions among male and female. Further, as the mean value of male is greater than female, it reveals that male consider capital appreciation as the major factor when compared to female.

Table 1.3 Table showing factors influencing investment decision based on occupation

\begin{tabular}{|l|l|l|l|l|l|}
\hline Factors & $\begin{array}{l}\text { Mean } \\
\text { Salaried } \\
\text { N=268 }\end{array}$ & $\begin{array}{l}\text { Mean } \\
\text { Self } \\
\text { employed } \\
\text { N=93 }\end{array}$ & $\begin{array}{l}\text { Mean } \\
\text { Others } \\
\text { N=13 }\end{array}$ & F test & Level of significance \\
\hline Capital appreciation & 4.19 & 4.31 & 4.54 & 1.948 & 0.144 \\
\hline Tax Benefit & 3.26 & 3.53 & 3.62 & 2.499 & 0.084 \\
\hline Expected Returns & 4.52 & 4.14 & $\mathbf{4 . 5 4}$ & 12.937 & $\mathbf{0 . 0 0 0}$ \\
\hline Financial Security & 4.12 & 4.10 & 4.00 & 0.216 & 0.806 \\
\hline Liquidity & 4.08 & $\mathbf{4 . 5 6}$ & 3.92 & 14.086 & $\mathbf{0 . 0 0 0}$ \\
\hline Risk minimization & 3.06 & 2.82 & 2.92 & 1.547 & 0.214 \\
\hline
\end{tabular}

Table 1.4 shows that there is significance differences in individual considering investment decision factors such as expected return and liquidity among various occupation group. There is no significance differences while considering the other factors such as capital appreciation, tax benefit, financial security, risk minimization on the basis of occupation. Self-employed group consider liquidity as the major factor for investment decision as they need immediate money to face the financial crisis at their business. The people from business community and professionals give more preference to the liquidity.

Table 1.5 Factors influencing investment decisions based on Internet usage

\begin{tabular}{|l|l|l|l|l|l|l|}
\hline Factors & $\begin{array}{l}\text { Mean } \\
\text { 2yrs - 5 yrs } \\
\text { N=52 }\end{array}$ & $\begin{array}{l}\text { Mean } \\
\text { 6yrs to 8 yrs } \\
\text { N=74 }\end{array}$ & $\begin{array}{l}\text { Mean } \\
\text { 9 yrs - 10 yrs } \\
\text { N=80 }\end{array}$ & $\begin{array}{l}\text { Mean } \\
\text { Above } \\
\mathbf{1 0} \text { yrs } \\
\text { N=168 }\end{array}$ & F test & $\begin{array}{l}\text { Level of } \\
\text { significance }\end{array}$ \\
\hline $\begin{array}{l}\text { Capital } \\
\text { appreciation }\end{array}$ & 4.23 & 4.04 & 3.85 & $\mathbf{4 . 5 1}$ & 18.062 & $\mathbf{0 . 0 0 0}$ \\
\hline Tax Benefit & 3.31 & 3.27 & 3.31 & 3.39 & 0.228 & 0.877 \\
\hline $\begin{array}{l}\text { Expecting } \\
\text { Returns }\end{array}$ & 4.56 & $\mathbf{4 . 6 4}$ & 4.18 & 4.42 & 7.641 & $\mathbf{0 . 0 0 0}$ \\
\hline $\begin{array}{l}\text { Financial } \\
\text { Security }\end{array}$ & 4.25 & $\mathbf{4 . 2 6}$ & 3.82 & 4.14 & 6.437 & $\mathbf{0 . 0 0 0}$ \\
\hline Liquidity & $\mathbf{4 . 4 2}$ & 4.31 & 4.14 & 4.10 & 2.901 & $\mathbf{0 . 0 3 5}$ \\
\hline $\begin{array}{l}\text { Risk } \\
\text { minimization }\end{array}$ & 2.65 & 2.78 & 2.95 & $\mathbf{3 . 2 2}$ & 4.476 & $\mathbf{0 . 0 0 4}$ \\
\hline
\end{tabular}

Table 1.5 shows that there is a significance difference in individual considering investment factors for most of the attributes such as capital appreciation, expecting returns, financial security, liquidity, risk minimization in investment decisions among various group of internet usage period. Individual who uses internet more than 10 years consider capital appreciation as the major factor for investment decision. Individuals who 
uses internet 2- 5 years are not very comfortable to trade online. Even the individual who has only 6- 8 years experience in internet usage prefer financial security.

Table 1.6 Factors influencing investment decisions based on computer knowledge

\begin{tabular}{|l|l|l|l|l|l|l|}
\hline Factors & $\begin{array}{l}\text { Mean } \\
\text { Basic } \\
\mathbf{N = 1 3}\end{array}$ & $\begin{array}{l}\text { Mean } \\
\text { moderate } \\
\mathbf{N = 1 3 0}\end{array}$ & $\begin{array}{l}\text { Mean } \\
\text { advance } \\
\mathbf{N = 1 1 6}\end{array}$ & $\begin{array}{l}\text { Mean } \\
\text { Highly } \\
\text { skilled } \\
\text { N=115 }\end{array}$ & F test & $\begin{array}{l}\text { Level } \\
\text { significance }\end{array}$ \\
\hline $\begin{array}{l}\text { Capital } \\
\text { appreciation }\end{array}$ & 4.00 & $\mathbf{4 . 4 7}$ & 4.24 & 3.99 & 9.212 & $\mathbf{0 . 0 0 0}$ \\
\hline Tax Benefit & 3.23 & 3.42 & 3.16 & 3.43 & 1.058 & 0.212 \\
\hline Expected Returns & $\mathbf{4 . 6 9}$ & 4.43 & 4.66 & 4.17 & 12.822 & $\mathbf{0 . 0 0 0}$ \\
\hline Financial Security & 4.31 & 4.19 & 4.09 & 4.03 & 1.508 & 0.212 \\
\hline Liquidity & 4.54 & 4.23 & 4.08 & 4.23 & 1.840 & 0.139 \\
\hline
\end{tabular}

Table 1.6 shows that the individual while considering investment decision the following factors such as capital appreciation, expected returns, risk minimization are significantly differ on the basis of their computer knowledge level. Investors who has moderate knowledge and advance knowledge in computer, aims to gain capital appreciation and returns respectively by investing in various investment opportunities. Investors with Basic knowledge in computer invest mainly interested to minimize the risk

Table 1.7 Factors influencing investment decisions based on online trading usage

\begin{tabular}{|l|l|l|l|l|l|l|l|}
\hline Factors & $\begin{array}{l}\text { Mean } \\
\text { Below 2 yrs } \\
\mathbf{N = 1 0 1}\end{array}$ & $\begin{array}{l}\text { Mean } \\
\text { 2yrs-5yrs } \\
\mathbf{N = 9 8}\end{array}$ & $\begin{array}{l}\text { Mean } \\
\text { 6yrs-8yrs } \\
\mathbf{N = 6 1}\end{array}$ & $\begin{array}{l}\text { Mean } \\
\text { 9yrs-10yrs } \\
\text { N=37 }\end{array}$ & $\begin{array}{l}\text { Mean } \\
\text { Above 10 yrs } \\
\text { N=77 }\end{array}$ & F test & $\begin{array}{l}\text { Level } \\
\text { significance }\end{array}$ \\
\hline $\begin{array}{l}\text { Capital } \\
\text { appreciation }\end{array}$ & 4.18 & $\mathbf{4 . 5 5}$ & 4.13 & 4.24 & 3.99 & 7.307 & $\mathbf{0 . 0 0 0}$ \\
\hline Tax Benefit & 3.25 & 3.49 & 3.15 & 3.59 & 3.29 & 1.637 & 0.164 \\
\hline $\begin{array}{l}\text { Expecting } \\
\text { Returns }\end{array}$ & 4.34 & 4.54 & $\mathbf{4 . 8 7}$ & 4.27 & 4.13 & 14.743 & $\mathbf{0 . 0 0 0}$ \\
\hline $\begin{array}{l}\text { Financial } \\
\text { Security }\end{array}$ & 4.08 & 4.14 & 4.21 & 3.97 & 4.10 & 0.768 & 0.547 \\
\hline Liquidity & 3.76 & 4.35 & 4.28 & 4.22 & $\mathbf{4 . 4 9}$ & 12.610 & $\mathbf{0 . 0 0 0}$ \\
\hline $\begin{array}{l}\text { Risk } \\
\text { minimization }\end{array}$ & 3.10 & $\mathbf{3 . 1 6}$ & 2.97 & 3.15 & 2.60 & 3.172 & $\mathbf{0 . 0 1 4}$ \\
\hline
\end{tabular}

Table 1.7 shows that individual considering investment decision factors such as capital appreciation, return expectation, liquidity, minimizing risk significantly differ according to the number of years they trade online in investment. By analysing the mean value, it is observed that individual who trade online more than 10 years gives importance to liquidity factor. The investors who has been trading online 2 years to 5 years are more active in gaining capital appreciation and regular return.

\section{LIMITATION OF THE STUDY:}

There are few limitation to the present study that should be considered for the future research.

$>$ Sample population is drawn only from Chennai City.

$>$ The data is collected from individual investors alone. Institutional investors are avoided.

\section{CONCLUSION}

There are many factors which directly or indirectly, influence the individual investment decisions. The factors chosen for the analysis are capital Appreciation, tax benefit, expected return, liquidity, risk minimization, financial security. The study attempts to find out influences of demographical profile on the factors influencing investment decision. The results proved that factors of selection of investment varies according to gender, age, occupation, usage of internet, level of computer knowledge, usage of online trading.

\section{REFERENCE}

1. Dhiraj Jain and Nikhil Mandot .2012.“ Impact of Demographic Factors on Investment Decision of Innvestors in Rajasthan", Journal of Arts, Science and Commerce. Vol.III Issue. 2(3).PP.81-92.

2. Kabra. G., Mishra, Prashant . K. and Dash, Manoj K.2010. "Factors Influencing Investment Decisions of Generations in India: An Econometric Study. Asian Journal of Management Research, Vol.1(1). PP: 308-328.

3. Monoj Kumar Dash, GauravKabra, Prashant Kumar Mishra . 2010. "Factors Influencing Investment Decision of Generation inn India: An Econometric Study" Asian Journal of Management Research. Online Journal.PP.308326.

4. Pandiyan L. and Aranganathan $\mathrm{T}$. 2012."Savings and 
Investments Attitude of Salaried Class in Cuddalore District", JOSR Journal of Business and Management.Vol.1 Issue.1 PP.40-49.

5. Parihar.B.B.S and Sharma K.K. 2012.“An Empirical Study of the Investment Preference of Salaried Employees, Technofame". A Journal of Multidisciplinary Advance Research, Vol.1 No.2, PP. 39-48.

6. Parimalakanthi . K. and Ashok Kumar . M. 2015., "A Study Pertaining to Investment behaviour of Individual Investors of Advance Research in computer 'science and Management Studies. Vol.3, Issue.6, PP.149-156

7. Pestonjee, D.M., and BalsaraAnita ,H. 2000. “ The Role of Working Woman “.Econpapers, Working Papers 2000-1204. Working papers from Indian Institute Management Ahmedabad, Research and Publication Department.

8. Poongavanam, S., Sait, M. I., Srinivasan, \& Rengamani. (2017). Amana investment and amana bank - A comparative study between prepublic issue and post-public issue. International Journal of Mechanical Engineering and Technology, 8(7), 985-991.

9. Ramanujam and Chitra Devi. 2012. "A Study on Impact of Socio-Economic Profile on Investment Pattern of Salaried and Business People in Coimbatore City" International Journal of Management and Information Technology, Vol.2 No. 1, PP.67-77.'

10. Satyanarayana.I, Sindhu.B.CMaruthi.D(2015), "Review on Portfolio Management", International Journal of Advance Research in Computer Science and Management Studies, Vol.3 Issue.2, PP.349-354.

11. Saugat Das and Ritikajain. 2014. "A Study on the Influence of Demographical Variables onn the Factors of Investment - A Perspective on the Guwahati Region", International Journal of Research in Humanities, Arts and Literature. Vol.2, Issue.6 PP. 98-102.

12. Shinde .C.M and PriyankaZanvar .2010. "An Empirical Study on Factors Influencing in Investment Decision making in Pune", International Research Journal of Management and Commerce, Vol.1, Issue.6, PP. 10-23

13. Thulasipriya .2015."A Study on the Investment Preference of Government Employees on Various Investment Avenues".International Journal of Management Research and Social Sciences, vol.2, Issue.1, PP.9-16.

14. Thiruvasagam, G., \& Rajasekar, D. (2017). Customer options in wealth management with reference to mutual funds, chennai. International Journal of Economic Research, 14(4), 345-352.

15. Uma maheswari and Ashok Kumar. 2014. "A Special Study on Coimbatore based Salaried Investors' Awareness, Attitude, Expectation and Satisfaction over their Investments". International Journal of Research in Business Management.Vol.2, Issue. 8. PP. 49-58.

16. Vettriselvan R., Sathya M., \& Velmurugan T. (2018), Productivity and Profitability Mechanical Engineering Entrepreneurs: Business Perspective, International Journal of Mechanical Engineering and Technology, 9(8): 758765 . 